\title{
PENGGUNAAN LINGKUNGAN SEKOLAH SEBAGAI SUMBER BELAJAR DALAM MENINGKATKAN HASIL BELAJAR BIOLOGI
}

\author{
St. Syamsudduha \\ Fakultas Tarbiyah dan Keguruan UIN Alauddin Makassar \\ Kampus II: Jalan Sultan Alauddin Nomor 36 Samata-Gowa \\ Email: syamsudduha@yahoo.com \\ Muh. Rapi \\ Fakultas Tarbiyah dan Keguruan UIN Alauddin Makassar \\ Kampus II: Jalan Sultan Alauddin Nomor 36 Samata-Gowa \\ Email: mrapi@uin-alauddin.ac.id
}

\begin{abstract}
Abstrak:
Penggunaan lingkungan sekolah dalam pembelajaran dimaksudkan menarik perhatian peserta didik materi yang berhubungan dengan lingkungan. Belajar dengan pendekatan lingkungan berarti peserta didik mendapatkan pengetahuan dan pemahaman dengan cara mengamati sendiri apa-apa yang ada di lingkungan sekitar, baik di lingkungan rumah maupun lingkungan sekolah. Hasil belajar adalah ukuran yang menyatakan seberapa jauh tujuan pembelajaran yang telah dicapai khususnya pada pelajaran Biologi dengan menggunakan lingkungan sekolah dalam pembelajaran. Hasil penelitian tentang penggunaan lingkungan sebagai sumber belajar disimpulkan dapat peningkatan hasil belajar Biologi siswa Kelas VII MTs.
\end{abstract}

\begin{abstract}
:
The use of the learning environment in the schools is intended to attract students attention in instructional materials that is related to the environment. Learning by using environmental approach means that the students acquire knowledge and understanding by observing something in the environment, both in the home and school environment. Learning outcome is a measurement of how far the learning objectives have been achieved, especially in Biology lessons using the school learning environment. The results of research on the use of the environment as a learning resource concluded that it can increase students' learning outcomes in Biology Class at the seventh grade of Islamic junior high school.
\end{abstract}

Kata kunci:

Lingkungan, sumber belajar, hasil belajar.

PENDIDIKAN memiliki peran strategis dalam meningkatkan kualitas sumber daya manusia dan upaya mewujudkan cita-cita bangsa Indonesia dalam mewujudkan kesejahteraan umum dan mencerdaskan kehidupan bangsa. Peran strategis inilah yang kemudian mengarahkan pendidikan pada fungsinya dalam mengembangkan kemampuan dan membentuk watak serta peradaban bangsa yang bermartabat dalam rangka mencerdaskan kehidupan bangsa. Terkait dengan hal tersebut, di Indonesia pendidikan nasional bertujuan untuk pengembangan potensi peserta didik agar menjadi manusia yang beriman dan bertakwa kepada Tuhan Yang Maha Esa, berakhlak mulia, sehat, berilmu, cakap, kreatif, mandiri, dan menjadi warga negara yang demokratis serta bertanggung jawab. ${ }^{1}$ 
Kualitas pendidikan tidak hanya ditentukan oleh sistem pendidikan, akan tetapi ditentukan oleh mutu tenaga pengajar. Tenaga pengajar yang dimaksud adalah tenaga pengajar yang mampu memberikan pembelajaran kepada siswa sehingga lebih mengerti dan memahami pelajaran yang dipelajarinya. Oleh karena itu, diperlukan beberapa faktor pendukung, antara lain; metode pembelajaran dalam penyajian materi kepada siswa. Guru atau tenaga pengajar dalam menyajikan materi tidak hanya fokus pada materi pelajaran saja, melainkan membantu siswa untuk berinteraksi dengan berbagai sumber belajar dalam mendapatkan pengetahuan, keahlian, dan keterampilan serta sikap yang menuju kepada perubahan tingkah laku baik secara kognitif, afektif, dan psikomotorik.

Salah satu faktor yang turut memengaruhi berhasilnya pencapaian tujuan pendidikan yaitu menciptakan adanya sistem lingkungan (setting) belajar yang lebih kondusif dalam proses pembelajaran. Sistem lingkungan belajar ini sendiri dipengaruhi oleh beberapa komponen yang saling memengaruhi. Komponen tersebut adalah sumber daya manusia, yaitu guru dan siswa, serta lingkungan belajar serta perangkat pendukung pembelajaran.

Ada anggapan keliru yang sering digunakan dalam mendefinisikan "kelas" sebagai tempat belajar yang dibatasi oleh dinding dan atap (dalam suatu ruangan). Anggapan ini dikatakan keliru, karena kelas sebagai tempat belajar bukan hanya dalam ruangan, tetapi proses pembelajaran dapat saja berlangsung di luar kelas (baca: Lingkungan). Anggapan ini sering digunakan tanpa mempertimbangkan bahwa lingkungan sangat berpengaruh terhadap proses pembelajaran, khususnya dalam bidang studi biologi. Jika akan memaksimalkan pembelajaran biologi, maka lingkungan dapat dijadikan sebagai bahan pembelajaran, misalnya saja pada pembelajaran mengenai ekosistem, dapat memanfaatkan lingkungan yang ada di sekitar sekolah.

Pemanfaatan lingkungan sekolah sebagai sumber belajar dalam proses pembelajaran yang dimaksud agar siswa dapat berpikir secara mandiri, kreatif, dan mampu menyesuaikan diri dengan permasalahan pembelajaran biologi.

Dengan demikian, dapat dikatakan bahwa salah satu faktor berhasilnya pendidikan adalah faktor situasi lingkungan. Situasi lingkungan di sini meliputi lingkungan fisik, lingkungan teknis, dan lingkungan sosial. Sebab tanpa adanya situasi lingkungan yang mendukung maka keberhasilan pembelajaran biologi tidak akan tercapai dengan baik, tetapi apabila lingkungan berpengaruh secara negatif terhadap pendidikan maka lingkungan itu menjadi pembatas pendidikan.

Kelebihan dalam pemanfaatan lingkungan sebagai sumber belajar yaitu:

1. Membuat siswa mendapatkan informasi berdasarkan pengalaman langsung;

2. Lebih komunikatif;

3. Membuat pelajaran lebih konkrit;

4. Membuat siswa mengenal dan mencintai lingkungan;

5. Penerapan ilmu menjadi lebih mudah sesuai dengan permasalahan yang dihadapi dalam kehidupan sehari-harinya. ${ }^{2}$

Untuk mengetahui efektifitas penggunaan lingkungan sebagai sumber belajar efektif dalam meningkatan hasil belajar, khususnya pokok bahasan pencemaran ling- 
kungan, maka dilakukan penelitian pada sekolah MTs Nurul Rahmat Bontolanra Kabupaten Takalar dengan permasalahan "Apakah dengan Penggunaan Lingkungan Sekolah Sebagai Sumber Belajar dapat meningkatkan hasil belajar siswa kelas VII MTs. Nurul Rahmat Bontolanra pada pokok bahasan Pencemaran Lingkungan".

\section{TINJAUAN TEORITIS}

\section{Pengertian Belajar}

Para ahli mengemukakan definisi belajar yang berbeda-beda. Namun, tampaknya ada secara umum dapat dikatakan bahwa perbuatan belajar mengandung perubahan dalam diri seseorang yang telah melakukan perbuatan belajar. Perbuatan itu bersifat intensional, positif-aktif dan efektif-fungsional. Sifat intensional berarti perubahan itu terjadi karena pengalaman atau praktik yang dilakukan pelajar dengan sengaja dan disadari, bukan kebetulan. ${ }^{3}$

James $\mathrm{O}$. Whittaker mengemukakan belajar adalah proses di mana tingkah laku ditimbulkan atau diubah melalui latihan atau pengalaman. Belajar adalah suatu proses yang dilakukan individu untuk memperoleh suatu perubahan tingkah laku yang sama secara keseluruhan, sebagai hasil pengalaman individu itu sendiri di dalam interaksi dengan lingkungannya. Dalam kesimpulan yang dikemukakan Abdillah, belajar adalah suatu usaha sadar yang dilakukan oleh individu dalam perubahan tingkah laku baik melalui latihan dan pengalaman yang menyangkut aspekaspek kognitif, afektif, dan psikomotorik untuk memperoleh tujuan tertentu. ${ }^{4}$

Belajar merupakan perubahan dari suatu hal yang belum diketahui menjadi tahu, atau dengan kata lain proses pendewasaan manusia. Belajar ini sangat penting bagi setiap manusia untuk menjalankan kehidupan sehari-hari. Di bawah ini akan dikemukakan teori belajar yaitu:

a. Belajar berhubungan dengan perubahan tingkah laku seseorang terhadap suatu situasi tertentu yang disebabkan oleh pengalaman yang berulang-ulang dalam situasi itu, di mana perubahan tingkah laku itu tidak dapat dijelaskan atau dasar kecenderungan respon pembawaan, kematangan atau keadaan sesaat seseorang.

b. Belajar terjadi apabila suatu situasi stimulus bersama dengan isi ingatan memengaruhi siswa sedemikian rupa sehingga perbuatanya berubah dari waktu sebelum mengalami situasi itu hingga waktu sesudah mengalami situasi.

c. Belajar adalah sikap perubahan yang terlatih mantap dalam tingkah laku yang terjadi sebagai suatu hasil dari latihan atau pengalaman.

d. Belajar adalah suatu perubahan di dalam kepribadian yang menyatakan diri sebagai suatu pola baru dari pada reaksi yang berupa kecakapan, sikap, kebiasaan, kepedulian atau sesuatu pengertian. ${ }^{5}$

Berdasarkan beberapa definisi yang telah dikemukakan sebelumnya maka dapat dipahami bahwa belajar adalah suatu proses untuk mendewasakan manusia di mana guru sebagai pengajar dan siswa sebagai subjek belajar. Agar proses itu dapat berlangsung dengan efektif dan efisien, maka guru dituntut memiliki kualifikasi tertentu dalam hal pengetahuan, kemampuan, sikap, tata nilai dan kepribadian. 


\section{Hasil Belajar Biologi}

Hasil belajar dimaksudkan untuk mengukur keberhasilan siswa yang berkaitan dengan aspek-aspek kognitif, afektif, psikomotorik. Hasil belajar siswa dalam bidang studi tertentu dapat diketahui dengan melakukan pengukuran yang dikenal dengan istilah pengukuran hasil belajar. Pengukuran hasil belajar ialah suatu tindakan atau kegiatan untuk melihat sejauhmana tujuan intruksional dapat dicapai oleh siswa setelah menampilkan proses belajar mengajar. Hasil belajar dapat diukur dengan menggunakan tes hasil belajar.

Menurut Zain belajar dapat dikatakan berhasil apabila:

a. Daya serap bahan ajar yang diajukan mencapai prestasi tinggi, baik secara individual maupun kelompok.

b. Perilaku yang digariskan dalam tujuan pelajaran telah dicapai oleh siswa, baik secara individu maupun kelompok. ${ }^{6}$

Sementara Muhibbin menyatakan bahwa hasil belajar merupakan penilaian untuk menggambarkan prestasi yang dicapai seorang siswa dengan kriteria yang telah ditetapkan. ${ }^{7}$ Hasil belajar diartikan sebagai terjadinya perubahan pada diri siswa ditinjau dari tiga aspek, yaitu kognitif, afektif, dan psikomotorik siswa. ${ }^{8}$

Berdasarkan pengertian hasil belajar yang telah dikemukakan di atas, maka dapat dipahami bahwa hasil belajar adalah ukuran yang menyatakan seberapa jauh tujuan pembelajaran yang telah dicapai khususnya pada pelajaran Biologi.

\section{Faktor-faktor yang Memengaruhi Hasil Belajar}

Faktor-faktor yang mempengaruhi hasil belajar ditinjau dari berbagai aspek dikemukakan Suryabrata sebagai berikut:

\section{Faktor Internal}

Faktor internal adalah faktor yang timbul dari diri individu, baik sebagai pendidik maupun sebagai anak didik. Kedua unsur ini sangat berpengaruh terhadap hasil belajar. Keduanya merupakan unsur yang tak terpisahkan dalam kegiatan individu.

Yang termasuk faktor internal yaitu :

1. Aspek Fisiologi (yang bersifat jasmani)

Kondisi umum jasmani dalam hal ini sering dianalogikan dengan kondisi kesehatan fisik. Aspek ini sangat memengaruhi hasil belajar, dan merupakan faktor yang tak terpisahkan dalam kegiatan individu.

2. Aspek Psikologi (yang bersifat rohani)

Faktor-faktor rohani siswa yang umumnya dipandang lebih esensial adalah tingkat kecerdasan atau intelegensi, sikap, bakat, minat, dan motivasi siswa.

a. Intelegensi

Intelegensi pada umumnya dapat diartikan sebagai komponen psiko-fisik untuk mereaksi rangsangan atau penyesuaian diri dengan lingkungan dengan cara yang cepat. Faktor intelegensi ini, sering juga disebut sebagai kemampuan otak manusia dalam merespons stimulan. 
b. Sikap siswa

Sikap adalah gejala internal yang berdimensi aktif berupa kecenderungan untuk mereaksi dan merespons dengan cara yang relatif tetap terhadap objek orang, barang, dan sebagainya, baik secara positif maupun negatif.

c. Bakat

Secara bakat umum (attitude) adalah kemampuan/potensi yang dimiliki seseorang untuk mencapai keberhasilan pada masa yang akan datang

d. Minat siswa

Secara sederhana, minat (interest) berarti kecenderungan dan kegairahan yang tinggi dan keinginan yang besar terhadap sesuatu.

e. Motivasi siswa

Motivasi adalah keadaan internal organisme baik manusia maupun hewan yang mendorongnya untuk membuat sesuatu. Dalam pengertian ini motivasi berarti pemasok daya untuk bertingkah laku secara terarah.

\section{Faktor Eksternal}

Yang tergolong faktor eksternal adalah :

1. Lingkungan sosial yang terdiri atas: lingkungan keluarga, lingkungan sekolah, masyarakat, dan kelompok.

2. Lingkungan non-sosial yang terdiri atas: lingkungan sekolah dan letaknya, rumah tempat tinggal keluarga siswa dan letaknya, alat-alat belajar. ${ }^{9}$

\section{Penggunaan Lingkungan Sebagai Sumber Belajar}

Lingkungan dalam pembelajaran IPA dapat diartikan sebagai "segala sesuatu yang ada di sekolah atau tempat tinggal siswa yang temasuk di dalamnya mahluk hidup maupun benda mati yang dapat dijadikan sebagai sumber belajar". Lebih lanjut dapat dikatakan bahwa lingkungan tersebut dapat menjadi objek pengamatan, sarana atau tempat melakukan percobaan/penyelidikan dan sebagai tempat mendapatkan informasi. Atas dasar pengertian tersebut, "lingkungan" merupakan sesuatu yang sangat penting, baik sebagai wahana maupun sebagai objek pembelajaran IPA. Oleh karena itu boleh saja ada anggapan bahwa banyak sekolah miskin atau kekurangan buku sumber atau alat peraga praktik buatan pabrik, tetapi tidak akan ada sekolah yang kekurangan lingkungan sebagai sumber belajar. ${ }^{10}$

Dalam pembahasan mengenai lingkungan, ada dua istilah yang sangat erat kaitannya tetapi berbeda secara gradual yaitu "alam sekitar" dan "lingkungan". Alam sekitar mencakup segala hal yang ada disekitar kita baik yang jauh maupun yang dekat letaknya, baik masa silam maupun yang akan datang tidak terikat pada dimensi waktu dan tempat. Sedangkan lingkungan adalah sesuatu yang ada di alam sekitar yang memiliki makna dan pengaruh tertentu pada individu. Istilah lain yang erat kaitannya dengan lingkungan adalah "ekologi" atau sering disebut "lingkungan hidup" ekologi terdiri atas bio-ekologi, geo-ekologi, dan kultur-ekologi. Bio-ekologi mencakup unsur lingkungan yang hidup meliputi manusia, tumbuh-tumbuhan dan 
binatang. Geo-ekologi mencakup alam seperti bumi, air, matahari, dan sebagainya. Kultur-ekologi mencakup budaya dan teknologi.11

Lingkungan sangat berhubungan dengan ilmu biologi, karena dalam pembelajaran biologi perlu pendekatan lingkungan, di mana pendekatan tersebut merupakan suatu pendekatan pembelajaran yang berusaha untuk meningkatkan ketertiban peserta didik melalui pendayagunaan lingkungan sebagai sumber belajar. Pendekatan ini berasumsi bahwa kegiatan pembelajaran akan menarik perhatian peserta didik jika ada yang di pelajari, diangkat dari lingkungan, sehingga ada yang dipelajari berhubungan dengan kehidupan dan berfaedah bagi lingkungan. Belajar dengan pendekatan lingkungan berarti peserta didik mendapatkan pengetahuan dan pemahaman dengan cara mengamati sendiri apa-apa yang ada di lingkungan sekitar, baik di lingkungan rumah maupun lingkungan sekolah. Oleh karena itu, peserta didik dapat menanyakan sesuatu yang ingin diketahui kepada orang lain di lingkungan mereka yang dianggap tahu tentang masalah tersebut. 12

Ada empat sumber belajar yang berkenaan langsung dengan lingkungan sebagai berikut:

a. Masyarakat kota atau desa sekeliling sekolah;

b. Lingkungan fisik di sekitar sekolah;

c. Bahan sisa yang tidak terpakai dan barang bekas yang terbuang yang dapat menimbulkan pemahaman lingkungan;

d. Peristiwa alam dan peristiwa yang terjadi dimanfaatkan cukup menarik perhatian siswa. ${ }^{13}$

Berdasarkan uraian di atas maka diketahui bahwa di sekitar sekolah terdapat berbagai macam sumber belajar yang dapat di manfaatkan oleh guru dan siswa dalam proses belajar mengajar. Dengan demikian siswa akan lebih mengenal lingkungannya, pengetahuan siswa akan lebih autentik, sifat verbalisme pada siswa dapat dikurangi serta siswa akan lebih aktif dan lebih banyak berlatih.

Dalam proses pembelajaran, lingkungan sebagai dasar pengajaran adalah faktor tradisional yang memengaruhi tingkah laku individu dan merupakan faktor belajar yang penting. Lingkungan belajar/pembelajaran atau pendidikan terdiri atas:

1. Lingkungan sosial yaitu lingkungan masyarakat baik kelompok besar maupun kelompok kecil;

2. Lingkungan personal meliputi individu-individu sebagai suatu pribadi berpengaruh terhadap individu pribadi lainnya;

3. Lingkungan alam (fisik) meliputi sumber daya alam yang dapat diberdayakan sebagai sumber belajar;

4. Lingkungan kultural mencakup hasil budaya dan teknologi yang dijadikan sumber belajar dan dapat menjadi faktor pendukung pengajaran. Dalam konteks ini termasuk sistem nilai, norma, dan adat kebiasaan. ${ }^{14}$

Pemanfaatan lingkungan sebagai sumber belajar seperti yang telah dijelaskan terdahulu sebenarnya sudah lama disadari oleh pendidik, namun kesadaran itu tidaklah berarti bahwa lingkungan sudah dimanfaatkan secara maksimal sebagai sumber belajar di sekolah dalam menunjang kegiatan belajar mengajar itu sendiri. Hal ter- 
sebut terjadi disebabkan oleh berbagai faktor, antara lain dari faktor guru, faktor dana, lembaga dan sebagainya. Sehubungan dengan hal pemanfaatan lingkungan sebagai sumber belajar tersebut, sangat bergantung pada kreativitas guru, kemampuan guru, waktu yang tersedia, dana yang tersedia, serta kebijakan-kebijakan lainnya.

Memanfaatkan lingkungan sebagai media pembelajaran memiliki banyak keuntungan. Beberapa keuntungan tersebut yaitu:

1. Menghemat biaya, karena memanfaatkan benda-benda yang telah ada di lingkungan.

2. Praktis dan mudah dilakukan, tidak memerlukan peralatan khusus seperti listrik.

3. Memberikan pengalaman yang riil kepada siswa, pelajaran menjadi lebih konkrit, tidak verbalistik.

4. Karena benda-benda tersebut berasal dari lingkungan siswa, maka benda-benda tersebut akan sesuai dengan karakteristik dan kebutuhan siswa. Hal ini juga sesuai dengan konsep pembelajaran kontekstual (contextual learning).

5. Pelajaran lebih aplikatif, maksudnya materi pelajaran yang diperoleh siswa melalui media lingkungan kemungkinan besar akan dapat diaplikasikan langsung, karena siswa akan sering menemui benda-benda atau peristiwa serupa dalam kehidupannya sehari-hari.

6. Media lingkungan memberikan pengalaman langsung kepada siswa. Dengan penggunaan lingkungan, siswa dapat berinteraksi secara langsung dengan benda, lokasi atau peristiwa sesungguhnya secara alamiah.

7. Lebih komunikatif, sebab benda dan peristiwa yang ada di lingkungan siswa biasanya mudah dicerna oleh siswa, dibandingkan dengan media yang dikemas. ${ }^{15}$

Dengan memahami berbagai keuntungan tersebut, seharusnya kita dapat tergugah untuk memanfaatkan semaksimal mungkin lingkungan di sekitar kita dalam rangka menunjang kegiatan pembelajaran. Lingkungan menyimpan berbagai jenis sumber dan media belajar yang hampir tak terbatas. Lingkungan dapat dimanfaatkan sebagai sumber belajar untuk berbagai mata pelajaran berdasarkan prinsip-prinsip atau kriteria pemilihan media dan menyesuaikannya dengan tujuan, karakteristik siswa dan topik pelajaran yang akan diajarkan.

\section{METODE PENELITIAN}

Penelitian ini merupakan penelitian tindakan kelas (Classroom Action Research). Jenis penelitian tindakan kelas yaitu peneliti menerapkan perlakuan dengan hati-hati, seraya mengikuti proses perlakuan dengan tahapan-tahapan pelaksanaan meliputi perencanaan, pelaksanaan tindakan, evaluasi dan refleksi secara langsung yang selanjutnya tahapan-tahapan tersebut dirangkai dalam satu siklus kegiatan. ${ }^{16}$

Subjek penelitian adalah siswa kelas VII MTs Nurul Rahmat Bontolanra Kab. Takalar semester II (Genap) berjumlah 27 orang pada tahun ajaran 2011.

Prosedur penelitian dilaksanakan dalam dua siklus. Siklus I dilaksanakan sebanyak 3 kali pertemuan ( $3 \times 45$ menit/ 3 jam pelajaran), dan siklus kedua selama 3 kali pertemuan ( $3 \times 45$ menit/3 jam pelajaran), tiap siklus dilaksanakan sesuai dengan perubahan yang dicapai. 
Secara rinci prosedur penelitian tindakan kelas ini dapat dijabarkan sebagai berikut:

\section{Pelaksanaan Kegiatan Pada Siklus I}

\section{Perencanaan Tindakan I}

a. Menelaah kurikulum materi pelajaran biologi untuk kelas VII IPA.

b. Mengidentifikasi masalah dan rumusan masalah berdasarkan pada permasalahan yang muncul dari siklus I.

c. Membuat skenario pembelajaran di kelas, dalam hal ini pembuatan Rencana Pelaksanaan Pembelajaran (RPP) sesuai dengan materi yang akan diajarkan.

d. Membuat alat bantu atau media pengajaran bila diperlukan.

\section{Pelaksanaan Tindakan I}

a. Menyiapkan siswa, berdoa, dan mengabsen siswa.

b. Menentukan tujuan pembelajaran

c. Mengajak siswa ke alam terbuka

d. Apersepsi dan mengadakan tanya jawab yang mengarah pada materi pokok.

e. Penggunaan lingkungan sebagai sumber belajar.

f. Menyusun materi pelajaran yang sesuai materi pokok bahasan pencemaran lingkungan.

g. Menyajikan materi dan membimbing siswa belajar dengan menggunakan lingkungan sekolah sebagai sumber belajar.

\section{Observasi}

a. Mengamati tiap kegiatan siswa melalui lembar observasi

b. Pengumpulan data melalui tes/LKS

c. Melakukan evaluasi

\section{Refleksi I}

Hasil yang didapatkan dalam hasil tes dikumpulkan serta dianalisis. Hasil analisis data yang didapatkan pada siklus I dipergunakan sebagai acuan untuk melaksanakan siklus berikutnya. Hal-hal yang belum berhasil ditindaklanjuti, hal yang dimaksud adalah siswa yang belum memenuhi tingkat ketuntasan sedangkan yang sudah baik dipertahankan atau ditingkatkan, sehingga hasil yang dicapai pada siklus berikutnya sesuai dengan yang diharapkan dan hendaknya lebih baik dari siklus sebelumnya.

\section{Tahap Pelaksanaan Siklus II}

Langkah-langkah yang dilakukan pada siklus II sama dengan siklus I dengan mengadakan perbaikan sesuai dengan hasil refleksi yang didapatkan pada tindakan evaluasi pada siklus I, dan seterusnya. 


\section{HASIL DAN PEMBAHASAN}

\section{Deskripsi Hasil Penelitian}

Proses penelitian ini dilakukan dalam dua siklus yang masing-masing siklus terdiri dari 4 tahapan, yaitu: (1) perencanaan tindakan, (2) pelaksanaan tindakan, (3) observasi (pengamatan), dan (4) refleksi tindakan.

\section{Siklus I}

Data hasil observasi yang digunakan untuk mengetahui aktivitas siswa selama penerapan pembelajaran lingkungan sekitar sekolah sebagai sumber belajar pada sisa kelas VII MTs. Nurul Rahmat Bontolanra Kabupaten Takalar, dapat ditunjukkan melalui tabel berikut:

Tabel 1.

Hasil Observasi Aktivitas Siswa Kelas VII MTs. Nurul Rahmat Bontolanra Kab. Takalar Selama Penggunaan Lingkungan Sekitar Sekolah Sebagai Sumber Belajar

\begin{tabular}{|c|l|c|c|c|}
\hline \multirow{2}{*}{ No } & \multicolumn{1}{|c|}{ Pengamatan } & \multicolumn{3}{|c|}{ Frekuensi Setiap } \\
\cline { 3 - 5 } & \multicolumn{1}{|c|}{ Pertemuan } \\
\hline 1. & Kehadiran & 24 & 24 & II \\
2. & Siswa yang melakukan kegiatan lain & 6 & 4 & 2 \\
\multirow{2}{*}{3.} & pada saat proses pembelajaran & & & \\
4. & Siswa yang bertanya & 3 & 4 & 6 \\
& Siswa yang menjawab pada saat & 3 & 2 & 4 \\
diajukan pertanyaan tentang materi & & & & \\
\hline
\end{tabular}

Hasil observasi siklus I ini menunjukkan adanya perubahan pola belajar siswa yang menjawab pertanyaan yang diajukan oleh peneliti bertambah, siswa yang melakukan kegiatan lain pada saat pembelajaran juga semakin berkurang, di samping itu mereka juga semakin aktif mengerjakan tugas yang diberikan oleh guru.

Adapun distribusi frekuensi skor pemahaman siswa adalah sebagai berikut: Tabel 2.

Distribusi Frekuensi dan Persentase Skor Pemahaman Siswa Kelas VII MTs. Nurul Rahmat Bontolanra Kab. Takalar Pada siklus I

\begin{tabular}{|c|c|c|c|c|}
\hline No & Skor & Kategori & Frekuensi & Persentase \\
\hline 1 & $0-34$ & Sangat rendah & 0 & 0 \\
\hline 2 & $35-54$ & Rendah & 0 & 0 \\
\hline 3 & $55-64$ & Sedang & 13 & 48,15 \\
\hline 4 & $65-84$ & Tinggi & 11 & 40,74 \\
\hline 5 & $85-100$ & Sangat tinggi & 3 & 11,11 \\
\hline \multicolumn{3}{|c|}{ Jumlah } & 27 & 100 \\
\hline
\end{tabular}


Tabel di atas menunjukkan bahwa persentase skor pemahaman siswa setelah diterapkan siklus I adalah sebesar $0 \%$ berada pada kategori sangat rendah dan kategori rendah, $48,15 \%$ berada pada kategori sedang, 40,74\% berada pada kategori tinggi, dan $11,11 \%$ berada pada kategori sangat tinggi.

Adapun presentase Ketuntasan Pemahaman Biologi yang diperoleh dari hasil belajar Biologi Siswa Kelas VII MTs. Nurul Rahmat Bontolanra setelah penerapan siklus I ditunjukkan pada tabel berikut ini:

Tabel 3.

Persentase Ketuntasan Pemahaman Siswa Kelas VII

MTs. Nurul Rahmat Bontolanra Kab. Takalar Pada Siklus I

\begin{tabular}{|c|c|c|c|c|}
\hline No & Skor & Kategori & Frekuensi & Persentase (\%) \\
\hline 1 & $0-64$ & Tidak Tuntas & 13 & 48,15 \\
\hline 2 & $65-100$ & Tuntas & 14 & 51,85 \\
\hline \multicolumn{3}{|c|}{ Jumlah } & 27 & 100 \\
\hline
\end{tabular}

Berdasarkan tabel di atas hasil belajar Biologi yang diperoleh siswa dengan nilai rata-rata dan pada ketuntasan hasil Belajar Biologi diperoleh 48,15\% dikategorikan tidak tuntas dan 51,85 \% di kategorikan tuntas. Dari hasil yang diperoleh ini, dapat dinyatakan bahwa tidak terjadi ketuntasan dalam proses belajar mengajar karena siswa yang mencapai ketuntasan hanya 14 siswa dari 27 siswa. Hal yang menjadi perhatian peneliti pada siklus I ini, adalah bagaimana memfokuskan perhatian siswa pada kegiatan belajar, sebab ternyata pada pembelajaran yang dilaksanakan, masih ditemukan siswa yang mengerjakan pekerjaan lain, misalnya bermain-main atau mengganggu temannya. Karena itu, peneliti berusaha untuk mengadakan perbaikan dengan cara melanjutkan penelitian siklus II untuk melihat perubahan aktivitas belajar dan pemahaman belajar biologi siswa.

\section{Siklus II}

Aktivitas belajar siswa pada penerapan pembelajaran Biologi pada siklus II melalui penggunaan lingkungan sekolah sebagai sumber belajar adalah sebagai berikut:

Tabel 4.

Hasil Observasi Aktivitas Siswa kelas VII MTs. Nurul Rahmat Selama Penggunaan Lingkungan sekitar Sekolah Sebagai Sumber Belajar

\begin{tabular}{|c|l|c|c|c|}
\hline \multirow{2}{*}{ No } & \multicolumn{1}{|c|}{ Pengamatan } & \multicolumn{2}{|c|}{ Frekuensi Setiap Pertemuan } \\
\cline { 2 - 4 } 1. & Kehadiran & 25 & 27 & III \\
\hline 2. & Siswa yang melakukan kegiatan lain & 2 & 1 & 1 \\
& $\begin{array}{l}\text { pada saat proses pembelajaran } \\
\text { Siswa yang bertanya }\end{array}$ & & & \\
3. & Siswa yang menjawab pada saat & 5 & 9 & 10 \\
4. & diajukan pertanyaan tentang materi & 6 & 12 & 15 \\
5elajaran & Siswa yang menyelesaikan tugas atau & & & \\
mengerjakan pekerjaan rumah & 19 & 27 & 27 \\
\hline
\end{tabular}


Dari hasil observasi siklus II terdapat perubahan pola belajar siswa yang menjawab pertanyaan yang diajukan oleh peneliti semakin bertambah, siswa yang melakukan kegiatan lain pada saat pembelajaran juga semakin berkurang, di samping itu juga semakin bertambah dalam mengerjakan tugas, baik tugas rumah maupun tugas sekolah. Distribusi frekuensi skor pemahaman siswa pada siklus II berikut ini:

Tabel 5.

Distribusi Frekuensi dan Persentase Skor Pemahaman Biologi Siswa Kelas VII MTs. Nurul Rahmat Bontolanra Setelah Penggunaan Lingkungan Sekolah sebagai Sumber Belajar Biologi pada siklus II

\begin{tabular}{|c|c|l|c|c|}
\hline No & Skor & \multicolumn{1}{|c|}{ Kategori } & Frekuensi & Persentase (\%) \\
\hline 1 & $0-34$ & Sangat rendah & 0 & 0 \\
\hline 2 & $35-54$ & Rendah & 0 & 0 \\
\hline 3 & $55-64$ & Sedang & 0 & 0 \\
\hline 4 & $65-84$ & Tinggi & 23 & 85,18 \\
\hline 5 & $85-100$ & Sangat tinggi & 4 & 14,82 \\
\hline \multicolumn{2}{|c|}{ Jumlah } & 27 & 100 \\
\hline
\end{tabular}

Dari tabel di atas menunjukkan bahwa persentase skor pemahaman siswa setelah diterapkan siklus II sebesar $0 \%$ berada pada kategori sangat rendah, kategori rendah dan kategori sedang, 85,18\% berada pada kategori tinggi dan 14,82 \% berada pada kategori sangat tinggi.

Adapun presentase Ketuntasan Pemahaman Biologi yang diperoleh dari hasil belajar Biologi Siswa Kelas VII MTs. Nurul Rahmat Bontolanra setelah Penerapan siklus II ditunjukkan pada tabel berikut ini:

Tabel 6.

Persentase Ketuntasan Pemahaman Siswa Kelas VII MTs. Nurul Rahmat Bontolanra Kab. Takalar pada siklus II

\begin{tabular}{|c|l|l|c|c|}
\hline No & \multicolumn{1}{|c|}{ Skor } & \multicolumn{1}{|c|}{ Kategori } & Frekuensi & Persentase (\%) \\
\hline 1 & $0-64$ & Tidak tuntas & 0 & 0 \\
\hline 2 & $65-100$ & Tuntas & 27 & 100 \\
\hline \multicolumn{3}{|c|}{ Jumlah } & 27 & $\mathbf{1 0 0}$ \\
\hline
\end{tabular}

Berdasarkan tabel di atas hasil belajar Biologi yang diperoleh siswa nilai ratarata dan pada ketuntasan hasil belajar Biologi diperoleh $0 \%$ dikategorikan tidak tuntas dan $100 \%$ tuntas. Dari hasil yang diperoleh ini, dapat dinyatakan bahwa terjadi ketuntasan dalam proses belajar mengajar karena siswa yang mencapai ketuntasan 27 siswa. Dari hasil yang diperoleh, ini dapat dinyatakan bahwa terjadi ketuntasan dalam proses belajar mengajar. Oleh karena itu, pemahaman belajar biologi itu telah tercapai atau tuntas, maka penelitian hanya dilaksanakan dalam dua siklus. 


\section{Pembahasan Hasil Penelitian}

Hasil penelitian tentang hasil belajar Biologi siswa setelah diterapkan penggunaan lingkungan sekitar sekolah pada kelas VII MTs. Nurul Rahmat Bontolanra Kab. Takalar dapat meningkatkan hasil belajar siswa. Peningkatan yang dimaksud adalah adanya kemauan siswa untuk belajar, di mana siswa tidak tinggal diam ketika diberikan kesempatan untuk menjawab pertanyaan yang diajukan dan bertanya ketika ada materi yang tidak dimengerti. Selain itu, adanya perubahan pada kebiasaan siswa di mana mereka yang sebelumnya belum mampu memecahkan masalah dengan usaha sendiri, malu bertanya dan menjawab pertanyaan yang diberikan oleh peneliti, akhirnya dapat melakukan aktivitas belajar yang lebih baik.

Hasil analisis data menunjukkan nilai rata-rata hasil belajar biologi siswa kelas VII MTs. Nurul Rahmat Bontolanra Kab. Takalar yang diajar dengan penggunaan lingkungan sekitar sekolah sebagai sumber belajar pada siklus I sebesar 66,48 sedangkan siklus II sebesar 74,25. Nilai rata-rata tersebut menunjukkan bahwa hasil belajar biologi siswa yang diajar melalui penggunaan lingkungan sekitar sekolah sebagai sumber belajar mengalami peningkatan nilai sebesar 7,77 dari siklus I ke siklus II.

Pada siklus I peneliti lebih mendorong siswa untuk mencintai pelajarannya terlebih dahulu, selama kegiatan pembelajaran berlangsung siswa yang sebelumnya menanggapi pelajaran dengan cuek, mulai ada kemauan untuk mengikuti pelajaran. Hal ini disebabkan adanya tugas yang diberikan pada setiap akhir pertemuan sampai pada akhir siklus I telah dapat terlihat kesenangan pada siswa untuk mengikuti pembelajaran tersebut. Akibatnya hasil belajar siswa mencapai skor rata-rata 66,48 \% dan jika dimasukkan ke dalam kategori skala lima berada pada kategori sedang.

Setelah diadakan refleksi kegiatan pada siklus I, maka dilakukan beberapa perbaikan kegiatan yang dianggap perlu, salah satunya memperbanyak kesempatan kepada siswa untuk bekerja sama dan menemukan masalah serta menyelesaikan masalah tersebut secara bersama-sama. Hal ini dilakukan untuk membangkitkan semangat belajar siswa dan lebih fokus pada pelajarannya sehingga dapat meningkatkan hasil belajar siswa pada siklus II.

Pada siklus II, terlihat bahwa kemauan siswa untuk belajar mengalami peningkatan, di mana siswa yang dulunya belum mampu memecahkan masalah dan menjawab pertanyaan yang ditanyakan peneliti, kini sudah mulai menemukan solusinya, dimana siswa mampu menjawab pertanyaan. Selain itu, juga dapat dilihat dari sejumlah siswa yang bertanya, siswa juga sudah percaya diri untuk tampil di hadapan teman-temannya untuk menjelaskan dan memaparkan jawaban atas pertanyaan yang diberikan. Setelah diberikan tes akhir siklus II, skor rata-rata yang dicapai adalah $74,25 \%$ dan jika dimasukkan ke dalam kategori skala lima berada pada kategori tinggi dibandingkan dengan akhir siklus I.

Berdasarkan hasil pelaksanaan tindakan pada siklus I dan II dapat dinyatakan bahwa terjadi peningkatan pemahaman melalui penggunaan lingkungan sekitar sekolah dari siklus satu ke siklus berikutnya. Hal tersebut dapat dilihat dari tabel berikut ini: 
Tabel 7.

Distribusi Frekuensi dan Persentase Skor Hasil Belajar Siswa Kelas VII MTs.

Nurul Rahmat Bontolanra Setelah Penggunaan Lingkungan Sekitar Sekolah pada Siklus I dan Siklus II

\begin{tabular}{|c|c|c|c|c|c|c|}
\hline \multirow{2}{*}{ No } & \multirow{2}{*}{ Skor } & \multirow{2}{*}{ Kategori } & \multicolumn{2}{|c|}{ Frekuensi } & \multicolumn{2}{c|}{ Persentase } \\
\cline { 4 - 7 } & & & Siklus I & Siklus II & Siklus I & Siklus II \\
\hline 1 & $0-34$ & Sangat rendah & 0 & 0 & 0 & 0 \\
2 & $35-54$ & Rendah & 0 & 0 & 0 & 0 \\
3 & $55-64$ & Sedang & 13 & 0 & 48,15 & 0 \\
4 & $65-84$ & Tinggi & 11 & 23 & 40,74 & 85,18 \\
5 & $85-100$ & Sangat Tinggi & 3 & 4 & 11,11 & 14,82 \\
\hline \multicolumn{2}{|r|}{ Jumlah } & $\mathbf{2 7}$ & $\mathbf{2 7}$ & $\mathbf{1 0 0}$ & $\mathbf{1 0 0}$ \\
\hline
\end{tabular}

Dari hasil deskriptif di atas menunjukkan bahwa skor rata-rata hasil belajar biologi siswa pada siklus I sebesar 66,48 dan setelah dikategorisasikan berada pada kategori rendah sedangkan pada siklus II terlihat bahwa skor rata-rata hasil belajar biologi siswa sebesar 74,25 yang berada pada kategori tinggi. Dengan demikian dapat disimpulkan bahwa penggunaan lingkungan sekitar sekolah dapat meningkatkan hasil belajar Biologi.

\section{SIMPULAN}

Berdasarkan hasil penelitian dan pembahasan tentang penggunaan lingkungan sebagai sumber belajar maka diperoleh kesimpulan bahwa terdapat peningkatan hasil belajar Biologi siswa Kelas VII MTs. Nurul Rahmat Bontolanra Kab. Takalar setelah penggunaan lingkungan sebagai sumber belajar. Peningkatan tersebut dapat dilihat dari skor hasil belajar sebagai berikut:

1. Hasil yang diperoleh sebelum penerapan penggunaan lingkungan pada kelas VII MTs. Nurul Rahmat Bontolanra yaitu skor rata-rata hasil belajar Biologi 66,48.

2. Hasil yang diperoleh setelah penggunaan lingkungan sebagai sumber belajar pada kelas VII MTs. Nurul Rahmat Bontolanra Kab. Takalar yaitu skor rata-rata hasil belajar Biologi pada siklus I yaitu 66,48 sedangkan pada siklus II yaitu 74,25. Adapun ketuntasan pada siklus I yaitu 51,85\% tuntas kemudian pada siklus II menjadi $100 \%$ tuntas.

\section{CATATAN AKHIR:}

1. Republik Indonesia. Undang-Undang Nomor 20 Tahun 2003 Tentang Sistem Pendidikan Nasional.

2. Sardiman, Media Pendidikan, Jakarta: PT. Raja Grafindo Persada, 2005, h. 121.

3. Qodri A. Azizy, Metodologi Pendidikan Agama Islam, Jakarta: Departemen RI Direktorat Jenderal Kelembagaan Agama Islam, 2002, h. 25.

4. Aunurrahman, Belajar dan Pembelajaran, Bandung: Penerbit Alfabeta, 2009, h. 35.

5. Mudyaharja Redja, Pengantar Pendidikan, Jakarta: PT. Raja Grafindo Persada, 2001, h. 7-8.

6. Aswan Zain, Strategi Belajar Mengajar, Jakarta: Rineka Cipta, 2000, h. 106. 
7. Muhibbin Syah, Psikologi Pendidikan dengan Pendekatan Baru, Bandung: Remaja Rosdakarya, 2004, h. 39.

8. Nana Sudjana, Penilaian Hasil Belajar, Bandung. PT, Remaja Rosdakarya, 2004, h. 39.

9. Sumardi Suryabrata, Psikologi Pendidikan, Jakarta: PT, Remaja Grafindo Persada, 2002, h. 39.

10. Sweetyhome.wordpress.com/.../pemanfaatan-lingkungan-sebagai-sumber-belajar/TembolokMirip. Di akses tanggal 27 Januari 2011.

11. Mulyasa, Menjadi Guru Profesional, Bandung: Remaja Rosdakarya, 2008, h. 100 .

12. Ibid, h. 101.

13. Rahmat, Model Penelitian Komunikasi, Bandung: PT. Remaja Rosdakarya, 2000, h. 196.

14. Sandhi S Ari, 2011. Pemanfaatan Laboratorium Lingkungan sebagai Media Pembelajaran IPA yang Bernilai Edukatif dan Ekonomis. http://iyoyee.wordpress.com/2007/11/08/artikelnon-penelitian-1. Di akses tanggal 27 Januari 2011.

15. Jeperis,wordpress.com//lingkungan-sebagai-sumber-belajar/-Tembolok-Mirip. Diakses tanggan 27 Januari 2007.

16. Suharsimi Arikunto, dkk., Penelitian Tindakan Kelas, Jakarta: Bumi Aksara, 2010, h. 27.

\section{DAFTAR PUSTAKA:}

Ari, Sandhi S, Pemanfaatan Laboratorium Lingkungan sebagai Media Pembelajaran IPA yang Bernilai Edukatif dan Ekonomis. http://iyoyee. Word-press.com/2007/11/08/artikel-nonpenelitian-1. Di akses tanggal 27 Januari 2011.

Arikunto, Suharsimi, dkk., Penelitian Tindakan Kelas, Jakarta: Bumi Aksara, 2010.

Aunurrahman, Belajar dan Pembelajaran, Bandung: Penerbit Alfabeta, 2009.

Azizy, Qodri A., Metodologi Pendidikan Agama Islam, Jakarta: Departemen RI Direktorat Jenderal Kelembagaan Agama Islam, 2002.

Jeperis, wordpress.com//lingkungan-sebagai-sumber-belajar/ - Tembolok - Mirip Diakses tanggal 27 Januari 2011.

Mudyaharja Redja, Pengantar Pendidikan, Jakarta: PT. Raja Grafindo Persada, 2001.

Mulyasa, Menjadi Guru Profesional, Bandung: Remaja Rosdakarya, 2008.

Rahmat, Model Penelitian Komunikasi, Bandung: PT. Remaja Rosdakarya, 2000.

Sardiman, Media Pendidikan, Jakarta: PT. Raja Grafindo Persada, 2005.

Sudjana, Nana, Penilaian Hasil Belajar, Bandung. PT, Remaja Rosdakarya, 2004.

Suryabrata, Sumardi, Psikologi Pendidikan, Jakarta: PT, Remaja Grafindo Persada, 2002.

Sweetyhome.wordpress.com/...pemanfaatan-lingkungan-sebagai-sumber-belajar/Tembolok-Mirip. Di akses tanggal 27 Januari 2011.

Syah, Muhibbin, Psikologi Pendidikan dengan Pendekatan Baru, Bandung: Remaja Rosdakarya, 2004.

Zain, Aswan, Strategi Belajar Mengajar, Jakarta: Rineka Cipta, 2000. 